\title{
Hydrolysis efficiency and enzyme adsorption on steam-pretreated spruce in the presence of poly(ethylene glycol)
}

\author{
Bálint Sipos ${ }^{\mathrm{a}, *}$, Dóra Dienes ${ }^{\mathrm{a}}$, Áron Schleicher ${ }^{\mathrm{a}, \mathrm{b}}$, Raffaella Perazzini $^{\mathrm{c}}$, Claudia Crestini $^{\mathrm{c}}$, \\ Matti Siika-aho ${ }^{d}$, Kati Réczey ${ }^{\mathrm{a}}$ \\ ${ }^{a}$ Budapest University of Technology and Economics, Department of Applied Biotechnology and Food Science, Szt. Gellért tér 4, 1111 Budapest, Hungary \\ ${ }^{\mathrm{b}}$ Chemical Works of Gedeon Richter Plc., Biotechnology, Gyömrői út. 19-21, 1103 Budapest, Hungary \\ ${ }^{c}$ Integrated Biorefinery Research Center, Dipartimento di Scienze e Tecnologie Chimiche, Tor Vergata University, Via della Ricerca Scientifica, 00133 Rome, Italy \\ ${ }^{\mathrm{d}}$ VTT Biotechnology, Technical Research Center of Finland, 02150 Tietotie 2, Espoo, Finland
}

\section{A R T I C L E I N F O}

\section{Article history:}

Received 29 January 2010

Received in revised form 14 April 2010

Accepted 25 May 2010

\section{Keywords:}

Lignocellulose

Cellulase

Hydrolysis

Enzyme adsorption

Poly(ethylene glycol)

\begin{abstract}
A B S T R A C T
Enzymatic hydrolysis of lignocellulosic substrates is one of the limiting steps in second generation bioethanol production. The effects of addition of poly(ethylene glycol) 4000 (PEG) on the efficiency and adsorption of cellulase components during the 72-h hydrolysis of steam-pretreated spruce were investigated. It was found that addition of PEG increased the amount of the enzyme components in the hydrolysis supernatant to varying degrees. As an effect of PEG addition the concentration of free proteins increased by $36 \%$ and the free overall cellulolytic activity (FPA) in the liquid fraction by $51 \%$. After 72 -h hydrolysis with PEG 48-68\% higher activities towards 4-methylumbelliferyl-saccharide substrates were recovered. The results suggest that the effect of PEG is based on the decrease of non-productive enzyme binding. The structure of the hydrolysis residues was studied by ${ }^{31} \mathrm{P}$ NMR.
\end{abstract}

(C) 2010 Elsevier Inc. All rights reserved.

\section{Introduction}

Enzymatic hydrolysis of cellulose has to be improved for effective production of ethanol from biomass. The improvement of this process step can be approached in several ways, such as increasing the accessibility of the substrate by modification of its structure and/or composition, improving the performance of the enzymes or decreasing the inhibition of cellulases [1].

Several previous studies have focused on the addition of extra enzyme components [2,3], other kinds of proteins (such as bovine serum albumin, BSA) [4], surfactants [5-8] or other chemicals (such as polymers) $[9,10]$. In an early study by Castanon and Wilke [11], a positive effect of the Tween 80 surfactant was reported for newspaper hydrolysis and was assumed to be from the higher residual filter paper activity (FPA). Park et al. [12] have also found favourable effects by using different surfactants in the hydrolysis of newspaper and reported a doubling of the amount of reducing sugars released when using octylphenyl- and nonyphenyl-ethers. Ooshima et al. [13] increased the conversion of pure cellulose (Avicel) by $35 \%$ using Tween 20. In their study, surfactant addition resulted in an enrichment of endoglucanases in the liquid phase, and thus they concluded that the surfactant enhances the synergistic action

\footnotetext{
* Corresponding author. Tel.: +361463 2269; fax: +3614633855

E-mail addresses: balint_sipos@mkt.bme.hu, siposbalint@gmail.com (B. Sipos).
}

of endoglucanase and cellobiohydrolase on the surface of cellulose.

More recently, the interest has turned from pure cellulose- and paper-substrates to lignocellulosics. It has also been found that higher conversion could be obtained in the hydrolysis by addition of surface active agents on substrates containing lignin [10]. An early report about the effect of surfactant on lignocellulose hydrolysis [14] showed that when using Tween, the optimal temperature of hydrolysis could be increased from 40 to $50{ }^{\circ} \mathrm{C}$. Using surfactant addition, the conversion of corn stover did not decrease when lower enzyme loadings were applied. The most important enhancing effect of surfactants on lignocelluloses is based on the fact that enzymes can adsorb unproductively to the surface of lignin [10]. Surfactants can prevent this kind of inactivation of cellulases. When BSA was added in the hydrolysis of pretreated corn stover, the 72-h hydrolysis yield was increased by $12 \%$ [4]. Loss of filter paper and $\beta$ glucosidase enzyme activities were found to be $80 \%$ and $95 \%$ after $72 \mathrm{~h}$, respectively, while $50 \%$ and $30 \%$ losses were observed with addition of BSA, respectively.

Eriksson et al. [6] reported a study in which a number of surfactants (such as Tween 20, Tween 80, Triton X-100, Agrimul and SDS) were tested for their ability to improve cellulose hydrolysis. Non-ionic surfactants were found to be the most effective. The addition of Tween 20 was found to be advantageous on the ethanol production in the case of simultaneous saccharification and fermentation of steam-pretreated spruce (SPS) [15]. When the 
structure of the surfactants was further investigated [9], it was found that the enhancing effect was increased when the ethylene oxide (EO) chain (hydrophilic tail) of the surfactant was longer. As the effect was rather dependent of the length of hydrophilic EO tail [9] instead of the hydrophobic part [5], pure poly(ethylene oxide) polymer (PEO) and poly(ethylene glycol) (PEG) were also studied, and were found to increase the hydrolysis of SPS. (PEG and PEO polymers are chemically similar, with polymers above 20,000 Da molecular weight called PEO and those below 20,000 Da, PEG.) In a study by Kristensen et al. [8] different non-ionic surfactants and PEG 6000 were screened in hydrolysis of wheat straw pretreated with various techniques and PEG was found to be efficient in the increase of cellulose conversion and increase the free endoglucanase concentration after hydrolysis. PEG was further investigated to find the optimal concentration and chain length to achieve the maximal enhancement of the hydrolysis of lignocellulose. PEG prevented enzyme inactivation effectively at greater than $2.5 \mathrm{~g} / \mathrm{l}$ concentration and $4000 \mathrm{Da}(n=91)$ molecular weight [9]. Börjesson et al. [10] have found that the adsorption of individual enzyme components, such as Trichoderma reesei Cel7A ( $\mathrm{CBH}$ I) and Cel7B (EG I), on isolated spruce lignin was reduced by the addition of PEG, and was especially pronounced for Cel7B (EG I). When the cellobiohydrolase Cel7A (CBH I) and an endoglucanase, Cel5A (EG II) were compared with regard to their adsorption affinity [16], it was observed that endoglucanase was bound to lignin to a higher degree. This higher binding is probably due to its open active site as compared to the tunnel-shaped active site of cellobiohydrolase. However, the importance of the CBM on enzyme adsorption has also been reported [10]. Adsorption of cellulases on SPS has been reported to be stronger at higher temperature [17].

When investigating the effect of PEG addition on the hydrolysis, lignin should get special attention. Lignin has a negative effect on the enzymatic hydrolysis of cellulose, and this is especially pronounced for softwood [18]. When lignocellulosic biomass is steam pretreated the lignin melts and dense agglomerations occur in the cell wall [19]. When PEO polymers were tested for fractionation of kraft pulps by flocculation [20], the main adsorption sites on lignin were identified as phenolic lignin residues where protons could form hydrogen bonds with the ether oxygens of PEO. PEG 4000 was also tested as an additive in water and dilute-acid pretreatment of corn stover [21]. PEG had little impact on the removal of lignin during hydrolysis in contrast with Tween 80 , while it had positive effect on the glucan conversion in enzymatic hydrolysis of the pretreated material.

In this work, the aim was to investigate the effect of PEG on the enzymatic hydrolysis of SPS, especially with regard to enzyme adsorption. The adsorption pattern was investigated in a 72-h enzymatic hydrolysis reaction of steam-pretreated spruce (SPS). The free FPA and $\beta$-glucosidase activities were measured in the supernatant of the hydrolysate at different sampling times, and other cellulase activity assays were performed on the final samples. The structure of the residual lignin after hydrolysis was investigated by ${ }^{31}$ P NMR spectroscopy.

\section{Materials and methods}

\subsection{Substrate}

Steam-pretreated spruce (SPS) was kindly donated by Guido Zacchi, Department of Chemical Engineering, Lund University. Before steam pretreatment, wood chips were impregnated with $2.5 \% \mathrm{SO}_{2}$ (based on moisture content) for $30 \mathrm{~min}$. The material was treated at $210^{\circ} \mathrm{C}$ for $5 \mathrm{~min}$. Pretreatment was optimised and has been further described by Stenberg et al. [22]. Pretreated material was stored at $-20^{\circ} \mathrm{C}$. Before hydrolysis, the liquid fraction was removed by filtration, and the solid fraction was washed with triple quantity of distilled water.

The solid fraction was analysed for carbohydrate and Klason lignin content. It contained $48.3 \%$ glucan, $0.28 \%$ arabinan, $0.96 \%$ mannan and $50.1 \%$ lignin, which is in accordance with other reports [23]. Determination of the composition is described below.

\subsection{Enzymes}

Enzymes were received from Novozymes A/S (Bagsvaerd, Denmark). Celluclast $1.5 \mathrm{~L}$ had an overall cellulase activity of $88.8 \mathrm{FPU} / \mathrm{ml}$, and $\beta$-glucosidase activity of $38.6 \mathrm{IU} / \mathrm{ml}$. Novozym 188 had $408 \mathrm{IU} / \mathrm{ml} \beta$-glucosidase activity. Enzyme activities were determined as described below.

Purification of T. reesei Cel7A(CBH I) and Cel6A(CBH II) was carried out according to the method described elsewhere [24].

\subsection{Enzymatic hydrolysis}

Enzymatic hydrolysis was performed at $50^{\circ} \mathrm{C}, \mathrm{pH} 4.8$ (in $0.05 \mathrm{M}$ sodium acetate buffer) in 100-ml screw-capped bottles at 300 rpm agitation speed using magnetic stirrers. Experiments were carried out in $50 \mathrm{~g}$ batches with a substrate concentration of $2 \%$ dry matter (DM). The low substrate concentration was applied to eliminate the mass transfer problems. Enzyme loading of Celluclast $1.5 \mathrm{~L}$ was $20 \mathrm{FPU} / \mathrm{g}$ dry substrate, and $\beta$-glucosidase was supplemented with Novozym 188 to $20 \mathrm{IU} / \mathrm{g}$ dry substrate. These relatively high enzyme dosages were chosen (i) because usually softwoods (like the one used in present study) need higher enzyme loading for efficient cellulose conversion [25]; (ii) in order to recover enzyme activities above the detection limit. Hydrolysis was also performed with addition of $2.5 \mathrm{~g} / 1 \mathrm{PEG}$ with an average molecular mass of $4000 \mathrm{~g} / \mathrm{mol}$ (Merck, Hochenbrunn, Germany). Samples were taken after $5 \mathrm{~min}$ and at 3, 6, 24, 48 and $72 \mathrm{~h}$. At each sampling time, three of the $50 \mathrm{~g}$ hydrolysis batches were centrifuged, and the supernatant was analysed for monomer sugars, enzyme activity (FP and $\beta$-glucosidase) and protein content. Degree of cellulose conversion was calculated from the amount of glucose released during the hydrolysis and expressed as a percentage of the theoretical maximum based on the glucan content of the pretreated material.

\subsection{Preparation of supernatant}

Before measuring the residual enzyme activities and protein content in the hydrolysis supernatant, $15 \mathrm{ml}$ of each sample was concentrated ten times, using an ultrafiltration device (Vivaspin 4 centrifugal filter unit with 10-kDa polysulfone membrane, Sartorius, Göttingen, Germany) and "washed" with buffer ( $5 \mathrm{ml}, 0.05 \mathrm{M}$ Na-acetate, $\mathrm{pH} 4.8$ ) to remove sugars and other small molar mass compounds that interfere with enzyme activity measurements.

\subsection{Enzyme activities and protein content}

Filter paper activity (FPA) measurements were carried out according to Mandels et al. [26], with the modification, that an enzyme dilution releasing $1 \mathrm{mg}$ glucose was used instead of $2 \mathrm{mg}$. To keep the $\mathrm{pH}$ at 4.8 , sodium acetate buffer $(0.05 \mathrm{M})$ was used

$\beta$-Glucosidase activity was measured according to Berghem and Pettersson [27] with minor modifications. The substrate was $5 \mathrm{mM} 4$-nitrophenyl- $\beta$-Dglucopyranoside (PNPG). A volume of $1 \mathrm{ml}$ preincubated substrate was mixed with $0.1 \mathrm{ml}$ diluted enzyme solution and incubated for $10 \mathrm{~min}$ at $50^{\circ} \mathrm{C}$. The reaction was terminated by addition of $2 \mathrm{ml}$ of $1 \mathrm{M} \mathrm{Na}_{2} \mathrm{CO}_{3}$ solution and then diluted with $10 \mathrm{ml}$ distilled water. The amount of the liberated 4-nitrophenol was measured at $400 \mathrm{~nm}$ against a blank.

Activity towards 4-methylumbelliferyl- $\beta$-D-lactoside (MULac, Sigma, St. Louis, MO, USA) was measured either with or without $50 \mathrm{mM}$ cellobiose $\left(\mathrm{Glu}_{2}\right)[28,29]$. The activity obtained without cellobiose was considered as the combined activities of Cel7A (CBH I) and Cel7B (EG I) and the one obtained in the presence of cellobiose as Cel7B (EG I). The Cel7A (CBH I) activity was calculated to be the difference between the activities on MULac and MULac with cellobiose. Activity against 4-methylumbelliferyl- $\beta$-D-cellotrioside (MUGlu 3 , Sigma, St. Louis, MO, USA) was also measured, and regarded as Cel5A (EG II) activity using the same reaction parameters as for Cel7B. In all cases, $\beta$-glucosidase was inhibited with $0.1 \mathrm{M}$ glucose when the activity was assayed against 4-methylumbelliferyl derivatives.

The endoglucanase (CMCase) activity towards $1 \%$ carboxymethyl-cellulose (CMC, Sigma-Aldrich, St. Louis, MO, USA) as a substrate prepared in $0.05 \mathrm{M}$ sodium acetate buffer ( $\mathrm{pH} 4.8$ ), was measured. One milliliter diluted enzyme was mixed with $0.5 \mathrm{ml}$ substrate and incubated at $50{ }^{\circ} \mathrm{C}$ for $30 \mathrm{~min}$. The reaction was terminated by addition of $3 \mathrm{ml}$ 2,4-dinitrosalicylic acid reagent. The reducing sugars released were analysed according to Miller using glucose calibration [30].

Protein content in the hydrolysis supernatant was measured according to Bradford [31] using Coomassie Brilliant Blue dye (Coomassie Blue G250, Sigma-Aldrich, St. Louis, MO, USA) with BSA as a standard.

\subsection{Enzyme adsorption}

Concentration of free proteins and residual activities was measured in the hydrolysis supernatant during the 72-h hydrolysis. In case of protein content, the decrease in concentration can be regarded as adsorption. In case of the enzyme activities, the decrease might also be due to other effects beside adsorption, like 
inactivation, therefore these values are regarded as "free enzymes in solution" or "recovered enzymes" in the text.

\subsection{Analysis}

Lignin and carbohydrate content of raw and pretreated materials were analysed using the NREL protocol [32] with minor modifications. The amount of oven dried $\left(105^{\circ} \mathrm{C}\right.$ ) sample was $0.5 \mathrm{~g}$ and was hydrolysed with $2.5 \mathrm{ml} 72 \%$ sulphuric acid at room temperature for $2 \mathrm{~h}$. After the reaction time was reached, this mixture was diluted with $72.5 \mathrm{ml}$ distilled water and the hydrolysis was continued at $121^{\circ} \mathrm{C}$ for $60 \mathrm{~min}$. The samples were filtered and washed with distilled water through G4 glass filter crucibles. The remaining lignin on the filter was dried at $105^{\circ} \mathrm{C}$, weighed and placed in a furnace at $550^{\circ} \mathrm{C}$ for $6 \mathrm{~h}$. The Klason lignin content was taken as the ash free residue after acid hydrolysis.

The monomer sugar concentrations of liquid samples from raw material analysis and enzymatic hydrolysis were determined with a Shimadzu HPLC system (Shimadzu, Kyoto, Japan) using an Aminex HPX-87H column (Bio-Rad, Hercules, CA, USA) at $65^{\circ} \mathrm{C}$. The eluent, $5 \mathrm{mM} \mathrm{H} \mathrm{SO}_{4}$ was used at a flow rate of $0.5 \mathrm{ml} / \mathrm{min}$. The concentration of carbohydrates was detected upon their refractive indexes. Before analysis, all samples were filtered through a $0.2 \mu \mathrm{m}$ pore size filter to remove solid particles.

\subsection{Gel electrophoresis and gel image analysis}

Sodium dodecyl sulphate polyacrylamide gel electrophoresis (SDS-PAGE) was run on $12 \%$ Bis-Tris pre-cast gels using NuPAGE Bis-Tris Electrophoresis System (Invitrogen, Carlsbad, CA, USA). The gel was stained using Colloidal Coomassie Stain [33]. For the quantitative analysis of the hydrolysis supernatant samples, the gel was scanned and the picture was analysed with AlphaEaseFC ${ }^{\mathrm{TM}}$ software (Alpha Innotech Corporation, San Leonardo, CA, USA). The percentage of the individual protein bands in SDS-PAGE contributing to the total density was calculated from the integrated area of the peaks. The average of three parallel runs of each hydrolysis supernatant sample, where the amount of total protein loaded varied between 1 and $4 \mu \mathrm{g}$, was used for calculations.

\subsection{Determination of lignin structure}

Quantitative ${ }^{31} \mathrm{P}$ NMR has previously been found to be suitable for the determination of lignin structure [34,35] as the technique provides quantitative and selective information of labile protons on hydroxyl groups with different chemical surroundings, which can be easily substituted with a phosphitilating agent marked with a ${ }^{31} \mathrm{P}$ isotope to be eliminated.

Milled spruce and solid hydrolysis residues were prepared as previously described by Crestini and Argyropoulos [36]. Thirty milligrams of dry lignin was accurately weighed and was dissolved in a solvent mixture composed of pyridine and deuterated chloroform, 1.6:1 $(\mathrm{v} / \mathrm{v})$ ratio $(0.4 \mathrm{ml})$. The derivatisation agent, 2-chloro-4,4,5,5-tetramethyl-1,3,2-dioxaphospholane (Aldrich, $0.1 \mathrm{ml}$ ), the internal standard (N-hydroxynaphthalimide) and the relaxation reagent (chromium(III) acetylacetonate) solution $(0.1 \mathrm{ml})$, were added. Quantitative ${ }^{31} \mathrm{P}$ NMR spectra were obtained on a Bruker 300 NMR spectrometer by using previously described methods $[37,38]$. The ${ }^{31} \mathrm{P}$ NMR data reported are averages of three phosphitylation experiments followed by quantitative ${ }^{31} \mathrm{P}$ NMR acquisition. The maximum standard deviation of the reported data was $2 \times 10^{-2} \mathrm{mmol} / \mathrm{g}$, while the maximum standard error was $1 \times 10^{-2} \mathrm{mmol} / \mathrm{g}$.

\section{Results and discussion}

\subsection{Cellulose conversion}

The effect of PEG on enzymatic hydrolysis of SPS was investigated at $50{ }^{\circ} \mathrm{C}$ and $2 \%$ DM substrate concentration. The average hydrolysis rate in the presence of PEG was significantly higher compared to the experiment without PEG (Table 1). The main difference in the hydrolysis rates was observed during the first $3 \mathrm{~h}$, and the amount of glucose released was nearly twofold higher when PEG was present than when it was not $(2.30$ and $1.36 \mathrm{mg} / \mathrm{ml} / \mathrm{h}$, respectively). Between the 3rd and the 6th hour, the hydrolysis rates were similar $(0.30$ and $0.33 \mathrm{~g} / \mathrm{l} / \mathrm{h})$. The hydrolysis rates decreased rapidly after $6 \mathrm{~h}$ in both cases, and no significant additional glucose release occurred. In both experiments, the final conversion (Fig. 1) was reached after $48 \mathrm{~h}$, with $80.7 \%$ and $95.4 \%$ conversion values without PEG addition and in the presence of $2.5 \mathrm{~g} / \mathrm{l} \mathrm{PEG}$, respectively. Thus, addition of the ethylene glycol polymer resulted in $18 \%$ increase in glucan conversion. The $85 \%$ conversion in the presence of PEG, obtained after $6 \mathrm{~h}$, corresponds to $1.52 \mathrm{~g} / \mathrm{l} / \mathrm{h}$ pro-

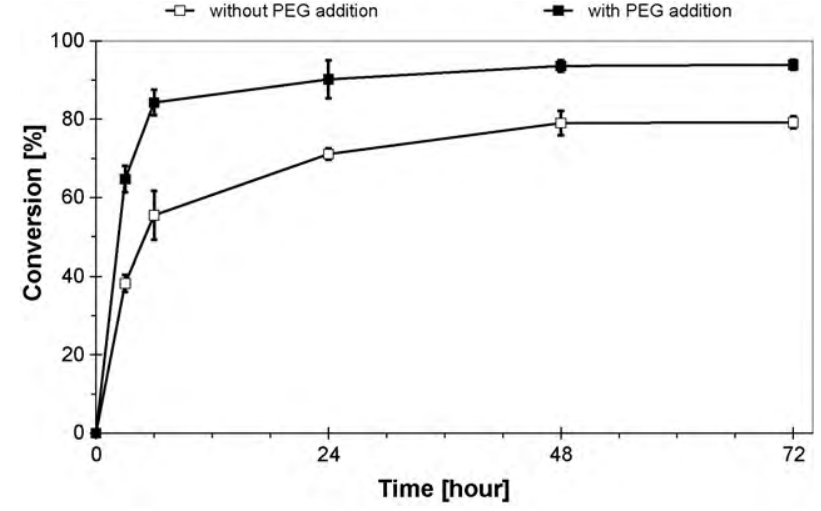

Fig. 1. Enzymatic conversion of SPS with and without addition of $2.5 \mathrm{~g} / \mathrm{l}$ PEG 4000. SPS (2\% DM) was hydrolysed at $\mathrm{pH} 4.8,50^{\circ} \mathrm{C}$ using $20 \mathrm{FPU} / \mathrm{g}$ DM Celluclast $1.5 \mathrm{~L}$, supplemented with Novozym 188 to $20 \mathrm{IU} / \mathrm{g}$ DM. Experiments were performed in triplicate, and the mean values and standard deviations are presented.

ductivity. The extent of cellulose breakdown obtained at 2\% DM SPS concentration was significantly higher compared to previous results [10] where a higher SPS concentration (5\% DM) but a lower cellulase dosage (14 FPU/g dry substrate cellulase and $28 \mathrm{IU} / \mathrm{g}$ dry substrate $\beta$-glucosidase) was used. The gain in glucose yield is probably because of the lower dry matter content and more efficient mixing.

\subsection{Free protein and enzyme activities in solution}

Free protein concentration and enzyme activities were measured in the supernatant of the hydrolysates. As most of the differences occurred during the first $24 \mathrm{~h}$ of the hydrolysis, changes in protein concentration and enzyme activities are presented in that period. Final concentrations together with a series of enzyme activities are discussed in a following section.

The decrease of protein content can be regarded as a reliable measure of adsorption, rather than enzyme activities that may be affected by any kinds of inactivation. Fig. 2 shows the change of the free protein concentration in the supernatant during the first $24 \mathrm{~h}$. In hydrolysis of SPS, the protein concentration decreased rapidly from 0.13 to $0.02 \mathrm{mg} / \mathrm{ml}$, while in the case of PEG addition, the protein concentration was $0.03 \mathrm{mg} / \mathrm{ml}$ after $3 \mathrm{~h}$. From the 3-24-h period, in case of PEG addition, higher free protein concentration

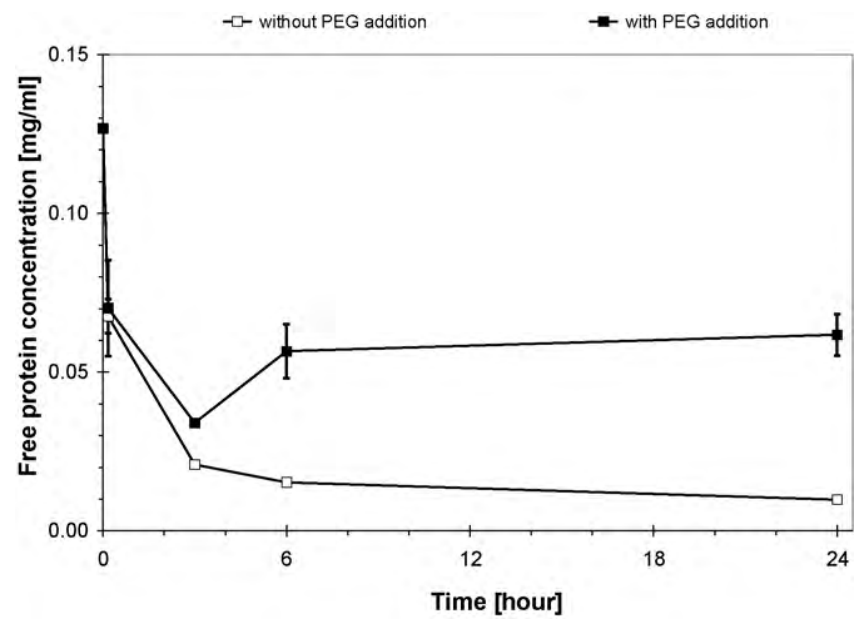

Fig. 2. Free protein concentration in the supernatant during the first 24-h hydrolysis of SPS. Hydrolysis was performed at $2 \% \mathrm{DM}, \mathrm{pH} 4.8$, and $50{ }^{\circ} \mathrm{C}$ using $20 \mathrm{FPU} / \mathrm{g}$ DM Celluclast $1.5 \mathrm{~L}$, supplemented with Novozym 188 to $20 \mathrm{IU} / \mathrm{g}$ DM. The mean values of triplicates and standard deviations are presented. 
Table 1

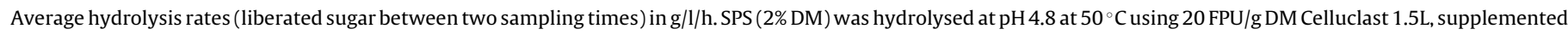
with Novozym 188 to 20 IU/g DM. 2.5 g/l PEG 4000 was added.

\begin{tabular}{|c|c|c|c|c|c|c|}
\hline \multirow[b]{2}{*}{ Hydrolysis intervals } & \multicolumn{6}{|c|}{ Average hydrolysis rates $(\mathrm{g} / \mathrm{l} / \mathrm{h})$} \\
\hline & $0-0.17 \mathrm{~h}$ & $0.17-3 \mathrm{~h}$ & $3-6 h$ & $6-24 h$ & $24-48 \mathrm{~h}$ & $48-72 \mathrm{~h}$ \\
\hline Hydrolysis without PEG & 0.91 & 1.36 & 0.30 & 0.07 & 0.02 & 0.00 \\
\hline Hydrolysis with PEG & 0.90 & 2.30 & 0.33 & 0.03 & 0.01 & 0.00 \\
\hline
\end{tabular}

could be observed in contrast to the base case, where the decrease in protein concentration was continued at a lower rate.

In the case of FPA (Fig. 3A), the activity has dropped from 0.39 to $0.02 \mathrm{FPU} / \mathrm{ml}$ (3-h hydrolysis) which is a 95\% decrease. PEG addition has resulted in an increase in the recovery of the enzyme activity, $0.15 \mathrm{FPU} / \mathrm{ml}$ was measured after $3 \mathrm{~h}$. The highest decrease in FP activity in the presence of PEG was observed during the first few hours, which fits well with the observation in protein concentration. This may be due to the cellulase adsorption on cellulose in the early stage of the hydrolysis, and this part of the enzymes has been solubilised when cellulose was hydrolysed. This phenomenon was not observed when PEG was not present, and can be due to the high amount of lignin-bound enzymes, and thus the ratio of cellulose-bound enzymes to lignin-bound ones would be rather low. The productive binding on cellulose reduced after the major part of cellulose had been hydrolysed, and thus the remaining part of the adsorbed proteins can be considered to be mostly unproductively bound enzymes. It must be noted, that due to the relatively high temperature of $50^{\circ} \mathrm{C}$, some denaturation may also occur on SPS in $72 \mathrm{~h}$ and enzyme inactivation due to shear force should also
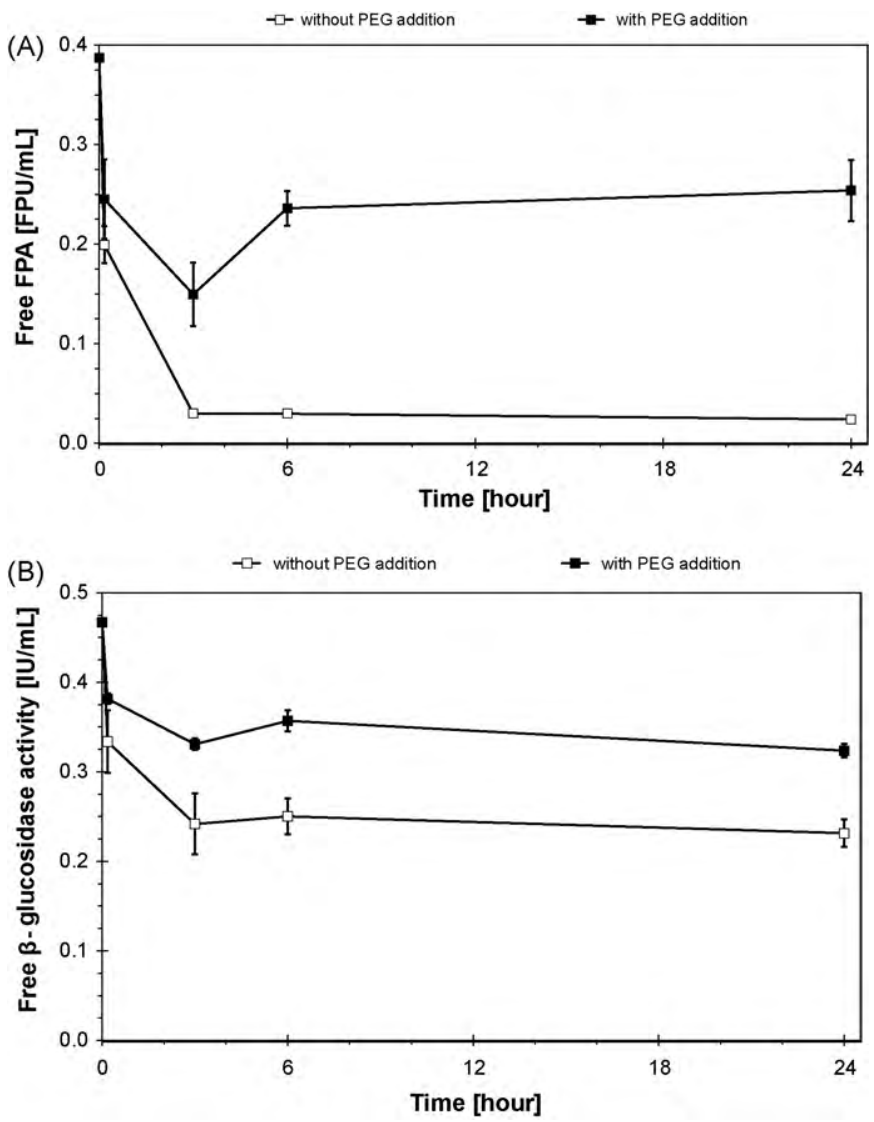

Fig. 3. Free enzyme activities in the hydrolysis supernatant: (A) FPA and (B) $\beta$ glucosidase. SPS (2\% DM) was hydrolysed at $\mathrm{pH} 4.8$ at $50^{\circ} \mathrm{C}$ using $20 \mathrm{FPU} / \mathrm{g}$ DM Celluclast 1.5L, supplemented with Novozym 188 to $20 \mathrm{IU} / \mathrm{g}$ DM. All experiments were performed in triplicate, and the mean values and standard deviations are presented. be considered. An earlier study [4] showed a similar adsorption pattern on corn stover by addition of BSA, where the adsorption of FPA ( $80 \%$ ) was significantly decreased (to $50 \%$ ) by the end of a $72-\mathrm{h}$ hydrolysis.

Decrease of $\beta$-glucosidase activity in the supernatant (Fig. 3B) was less pronounced than that of the overall cellulase complex. It must be noted, that $\beta$-glucosidases are not strictly cellulolytic enzymes because they are not active on the solid substrate; they do not have carbohydrate binding module (CBM), which has already been presented to be an important factor in enzyme adsorption on lignin [10]. The equilibrium of the bound enzymes was reached rapidly, and $52 \%$ of the initial activity was observed after $3 \mathrm{~h}$. When PEG was used, the $\beta$-glucosidase activity was measured as $71 \%$ of the initial enzyme activity after $3 \mathrm{~h}$. In both cases, a slight decrease in enzyme activity in the supernatant was observed, which could be due to other effects than adsorption.

There are contradictious results in the literature about $\beta$-glucosidase adsorption. Several papers reported significant $\beta$-glucosidase adsorption [4,39], while others observed less adsorption of $\beta$-glucosidases $[40,41]$, which are more comparable with our results. This may be explained by the structural and compositional differences between the substrates used and especially by different lignin structures of them, but there might be also other important differences in the experimental setup.

\subsection{Free enzyme activities and protein concentration recovered after $72 \mathrm{~h}$}

The free enzyme activities in the solution were monitored by measuring FP (overall cellulase), $\beta$-glucosidase, endoglucanase (CMCase), Cel7A, Cel7B and Cel5A (towards 4-methylumbelliferylsaccharide substrates) activities of the 72-h hydrolysate samples. The decrease of activities in the liquid fractions indicates the absence of the enzymes, suggesting that they have been adsorbed or inactivated during the hydrolysis.

Fig. 4 summarises the final protein content, FP, $\beta$-glucosidase, and endoglucanase (CMCase) activities in the hydrolysis supernatants after 72-h hydrolysis compared to the initial values. The loaded protein content was $0.126 \mathrm{mg} / \mathrm{ml}$, while at the end of the hydrolysis, 0.005 and $0.051 \mathrm{mg} / \mathrm{ml}$ were measured without and with PEG addition, respectively. The final FPA activities without and with PEG were observed to be 0.02 and $0.22 \mathrm{FPU} / \mathrm{ml}$, respectively, compared the loaded content of $0.39 \mathrm{FPU} / \mathrm{ml}$. The $\beta$-glucosidase activity decreased the least of all under both PEG and no-PEG conditions. After $72 \mathrm{~h}$ of hydrolysis without and with PEG, 0.20 and $0.30 \mathrm{IU} / \mathrm{ml}$ out of the loaded $0.43 \mathrm{IU} / \mathrm{ml}$ activities, were measured in the supernatant, respectively. The decrease in overall endoglucanase (CMCase) activity was even more pronounced during the hydrolysis, with only 0.07 and $0.87 \mathrm{IU} / \mathrm{ml}$ measured after $72 \mathrm{~h}$, which are very low compared to the initial $4.33 \mathrm{IU} / \mathrm{ml}$. Kristensen et al. [8] have also measured free endoglucanase activity in hydrolysis of wheat straw pretreated using different methods and with dyed CMC substrate. They observed that around 15\% of the loaded endoglucanase activity was in solution and it was increased to about $25 \%$ with addition of surfactants or PEG 6000 , which is in good accordance with our result. 


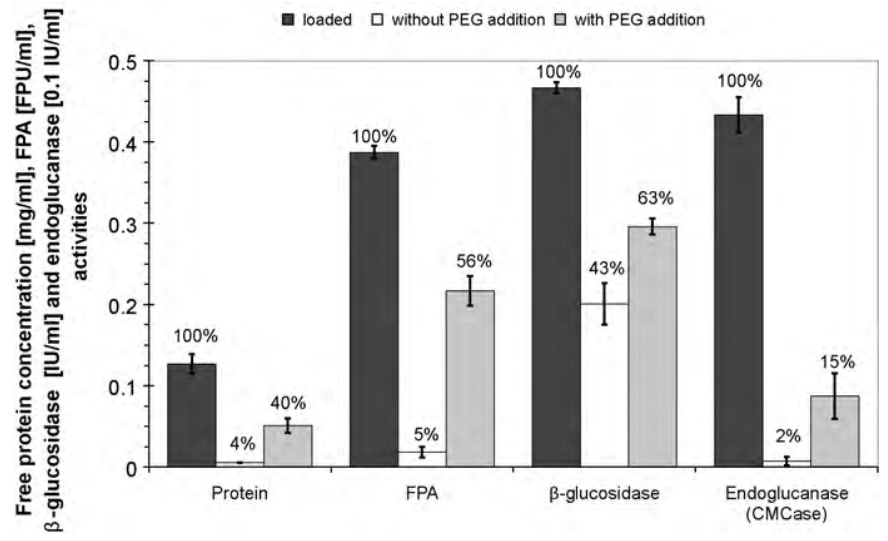

Fig. 4. Final activities (FPA $[\mathrm{FPU} / \mathrm{ml}], \beta$-glucosidase $[\mathrm{IU} / \mathrm{ml}]$, endoglucanase (CMCase) $[0.1 \mathrm{IU} / \mathrm{ml}]$ ) and protein content $[\mathrm{mg} / \mathrm{ml}]$ in the supernatant measured after $72 \mathrm{~h}$ of hydrolysis as compared to the initially loaded. SPS ( $2 \% \mathrm{DM})$ was hydrolysed at $\mathrm{pH} 4.8$ at $50^{\circ} \mathrm{C}$ using $20 \mathrm{FPU} / \mathrm{g}$ DM Celluclast $1.5 \mathrm{~L}$, supplemented with Novozym 188 to $20 \mathrm{IU} / \mathrm{g}$ DM. All experiments were performed in triplicate, and the mean values and standard deviations are presented.

As the result of the FP activity assay is heavily affected by the synergistic action of different enzyme components on the substrate, activity assays towards chromogenic derivatives were also used to investigate the decrease in the residual enzyme activities. These have previously been reported to be specific for individual enzyme components (using purified enzymes). The activity obtained in the presence of cellobiose on MULac substrate has generally been considered to be Cel7B (EG I). Cel5A (EG II) was reported to be the only known cellulase that acts on MUGlu 3 [42].

The combined Cel7A and Cel7B, Cel7B and Cel5A activities were measured in the hydrolysis supernatants obtained after the 72 -h hydrolysis. The initial activities and those obtained after $72 \mathrm{~h}$ of hydrolysis are presented in Fig. 5. All three showed decreased activity during the hydrolysis of SPS to a similar extent (Cel7A $6 \%$, Cel7B $4 \%$, and Cel5A $9 \%$ of the initial activity were detected). This observation is in good accordance with the result of the FPA assay (Figs. 3A and 4) and that of Eriksson et al. [43], where they found a similar extent of adsorption for purified Cel7A and Cel7B enzymes on SPS. When PEG was added to the hydrolysis mixture, the enzymes were successfully prevented from unproductive binding, and $73 \%, 72 \%$ and $57 \%$ of the initial enzyme activities,

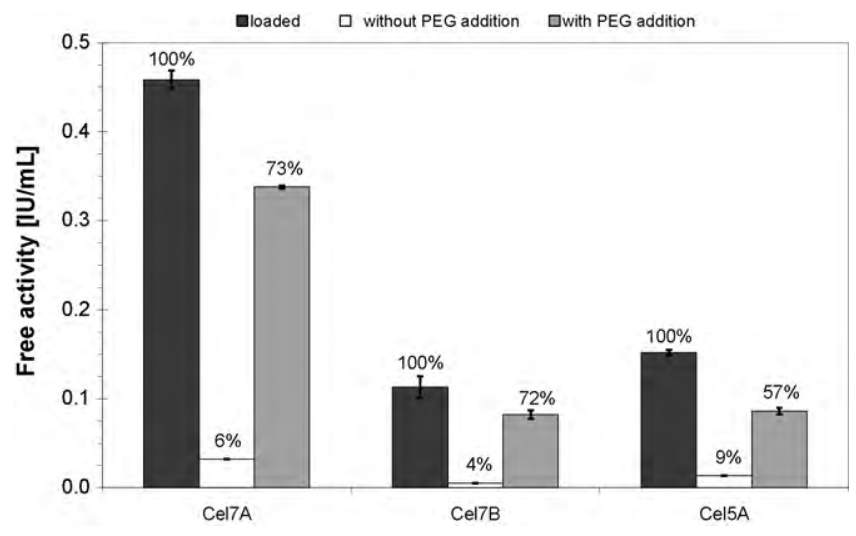

Fig. 5. Final activities ( $72 \mathrm{~h}$ ) of Cel7A, Cel7B and Cel5A compared to the initially loaded activities. SPS ( $2 \% \mathrm{DM}$ ) was hydrolysed at $\mathrm{pH} 4.8$ at $50^{\circ} \mathrm{C}$ using $20 \mathrm{FPU} / \mathrm{g}$ DM Celluclast $1.5 \mathrm{~L}$, supplemented with Novozym 188 to $20 \mathrm{IU} / \mathrm{g}$ DM. All experiments were performed in triplicate, and the mean values and standard deviations are presented. respectively, were still present in the liquid fraction. The fact, that enzymes from the same glycosyl hydrolase family (Cel7A and Cel7B) showed similar decrease in free activities towards methylumbelliferyl derivatives, may indicate that molecular properties also play an important role in the adsorption. The decrease of Cel7B and Cel5A endoglucanase activities (Fig. 5) was considerably lower than those that were measured on the CMC substrate (Fig. 4), where $2 \%$ and $15 \%$ of the loaded activity was detected without and with PEG, respectively. Comparing these results, we have to keep in mind that various endoglucanases hydrolyse the same substrate to a different extent (e.g., on CMC see Karlsson et al. [44]). Furthermore, there can be a significant difference in the affinities towards different substrates by a given enzyme component.

The results obtained show that the activity of the supernatants towards 4-methylumbelliferyl substrates decreased during hydrolysis of SPS. This effect could be significantly reduced by addition of PEG showing 55\% and $75 \%$ of the initially loaded activity remaining in the liquid phase, and $40 \%$ of the total protein content remaining in solution (Fig. 4). In a previous study [10], adsorption of individual enzyme components (Cel7A and Cel7B) at an enzyme dose of $1 \mu \mathrm{M}$ on SPS $(10 \mathrm{~g} / \mathrm{l})$ was tested in short time hydrolysis $(6 \mathrm{~h})$. It was found that both enzymes were highly adsorbed on SPS ( $90 \%$ and $87 \%$, respectively) but PEG had only a minor effect on the adsorption of these enzymes (decreased to $87 \%$ and $79 \%$, respectively). The amount of Cel7A is similar order of magnitude to the amount used in this study for cellobiohydrolases, but in case of endoglucanases, $1 \mu \mathrm{M}$ of the Cel7B is one order of magnitude higher than the amount assumed in Celluclast dose applied. They also found that PEG prevented enzyme adsorption to isolated spruce lignin $(60 \mathrm{~g} / \mathrm{l})$ and the adsorption of Cel7A and Cel7B was found to be $49 \%$ and $65 \%$, respectively, while in the presence of PEG, it was decreased to $5 \%$ for both enzymes. The results obtained in our study show that the addition of PEG increases cellulase activity in the liquid fraction of the hydrolysis mixture, and therefore results in a more complete degradation of cellulose. This is probably due to the decrease in unproductive binding of enzymes on the substrate, especially on lignin.

Since the decrease of enzyme activity may arise not only from unproductive binding but also from other kinds of inactivation, the adsorption of the two main cellulases secreted by T. reesei, Cel7A (CBH I) and Cel6A (CBH II) was analysed with gel electrophoresis, which is not affected by inactivation (Fig. 6). Adsorption of cellobiohydrolases was calculated from the protein concentration of the enzyme mixture used for hydrolysis (appears on the gel in the investigated range) and that of samples taken after 72-h hydrolysis and the percentage of the cellobiohydrolases contributes to the total protein density of the given lane on the gel. Comparing the bonding of the sum of the two cellobiohydrolases calculated from gel image analysis, shows adsorption of $97.5 \%$ and $45.7 \%$ in the supernatants without and with PEG, respectively. These adsorption values are in remarkably good agreement with the experimental data from the FPA measurements $(72 \mathrm{~h})$. However, it should be noted, that Cel7B (EG I) and other minor proteins which appear close to $\mathrm{CBH}$ enzymes on SDS-PAGE gel may interfere with cellobiohydrolases.

T. reesei culture broth contains about $80 \%$ cellobiohydrolases among cellulolytic proteins [45] while the amount of endoglucanases secreted is much lower. Cel7A $(\mathrm{CBH} \mathrm{I})$ is produced in the highest quantity followed by Cel6A (CBH II). Cel7B (EG I) is the most abundant endoglucanase in $T$. reesei enzyme preparations, and its amount is reported to be $6-10 \%$ of the cellulases [46]. Cel5A (EG II) is the second endoglucanase with regards to the quantity secreted $[42,47]$. All of the above mentioned cellulases have CBM (in contrast to Cel12A, EG III). 
Table 2

Functional groups detected and quantified in the hydrolysis residue of SPS. Evaluated by quantitative ${ }^{31} \mathrm{P}$ NMR after phosphylation of the samples.

\begin{tabular}{|c|c|c|c|}
\hline & $\begin{array}{l}\text { Milled wood lignin } \\
(\mathrm{mmol} / \mathrm{g})\end{array}$ & $\begin{array}{l}\text { Hydrolysis residue } \\
\text { of SPS ( } \mathrm{mmol} / \mathrm{g})\end{array}$ & $\begin{array}{l}\text { Hydrolysis residue of SPS with } \\
\text { PEG addition }(\mathrm{mmol} / \mathrm{g})\end{array}$ \\
\hline Aliphatic OH & 4.59 & 2.57 & 2.69 \\
\hline Condensed $\mathrm{OH}$ & 0.30 & 0.39 & 0.25 \\
\hline Guaiacyl OH & 0.60 & 0.57 & 0.50 \\
\hline p-Hydroxyphenyl OH & 0.070 & 0.067 & 0.004 \\
\hline Carboxyl group & 0.014 & 0.028 & 0.004 \\
\hline
\end{tabular}

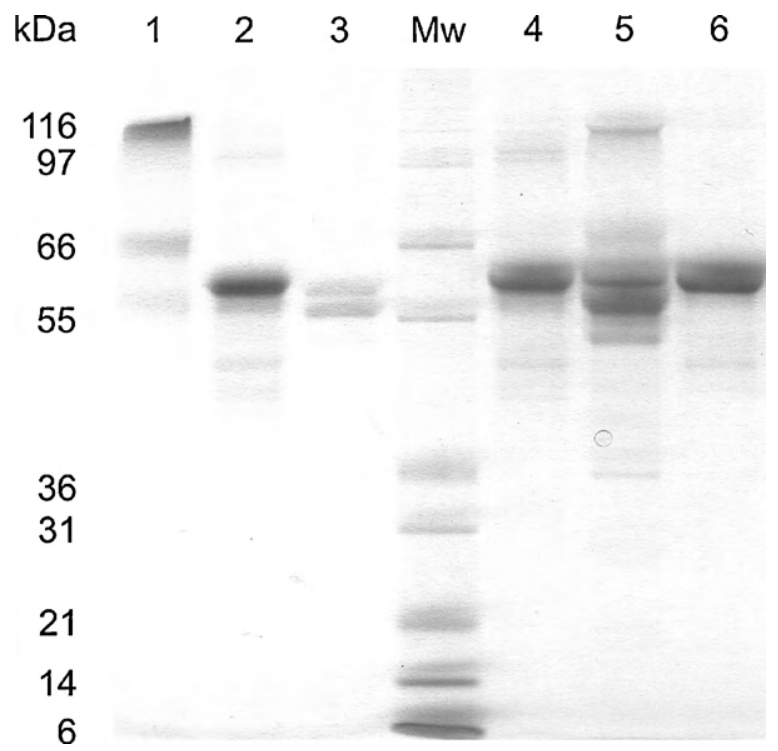

Fig. 6. SDS-PAGE analysis of the commercial enzymes used and hydrolysis supernatant samples taken after $72 \mathrm{~h}$ of hydrolysis together with purified T. reesei Cel7A (CBH I) and Cel6A (CBH II). The samples are as follows: (1) Novozym 188; (2) Celluclast 1.5L; (3) purified T. reesei Cel7A and Cel6A; (4) enzyme mixture of Novozym 188 and Celluclast 1.5L used in hydrolysis; (5) hydrolysis supernatant without PEG and (6) hydrolysis supernatant with PEG. The amount of total protein loaded on the gels was 2.5 and $2.0 \mu \mathrm{g}$ for the commercial enzymes; $1.0 \mu \mathrm{g}$ for the purified Cel7A and Cel6A; $2.0 \mu \mathrm{g}$ for enzyme mixture of Novozym 188 and Celluclast $1.5 \mathrm{~L} ; 2.1$ and $1.4 \mu \mathrm{g}$ for the hydrolysis supernatant samples. Staining was made with colloidal Coomassie Blue.

\subsection{Lignin structure}

Enzymatic hydrolysis of lignocelluloses may not only be a suitable technology for second generation ethanol processes, but also lignin in the residue can be further processed and upgraded to value added products, beside being used as solid biofuel. To utilise lignin, the carbohydrate should be removed from the solid fraction as much as possible and complete hydrolysis of cellulose is an option to achieve this goal. Because SPS carbohydrate hydrolysis was found to be efficient in the presence of PEG 4000, the hydrolysis residue was assessed by ${ }^{31} \mathrm{P}$ NMR and compared to milled wood lignin isolated from spruce. The lignin isolation method was previously found to be crucial step in lignin analytics [48]. ${ }^{31} \mathrm{P}$ NMR is an effective tool for lignin analysis and allows quantitative detection of the different classes of phenolic and aliphatic groups and carboxylic acids present in the polymer.

In Table 2, the amount of different hydroxyl groups present in milled wood lignin, hydrolysis residue and residue of hydrolysis carried out in the presence of PEG are reported. It is known that cellulases do not affect the lignin structure [48], while it can be significantly modified by steam treatments [19,49]. Li et al. have previously characterised steam explosion lignins and found that the $\beta-0-4^{\prime}$ linkages disappeared and that there was a slight increase in the amount of carboxyl groups in alkali extracted steam-pretreatment lignins [49] (same pretreatment parameters and equipment as we used on our substrate). An obvious decrease in the aliphatic hydroxyl groups due to steam pretreatment was also observed in our experiments, which is more than likely due to the disruption of hydroxylated side chain structures. It has been suggested $[19,49]$ that beside the side chain reactions, partial depolymerisation and repolymerisation also occur during steam pretreatment.

Slight differences were observed in the amount of condensed and guayacyl hydroxyl groups of the hydrolysis residues. The differences are probably due to the more effective removal of the cellulose polymer from the solid fraction, and therefore it is possible that the carbohydrate-lignin structures were disrupted.

\section{Conclusions}

Experimental results presented in this paper confirm that addition of PEG 4000 to the hydrolysis mixture sufficiently prevents cellulases from non-productive binding on SPS. A large decrease in total protein adsorption and increase of overall soluble cellulolytic activity was observed when PEG was applied in the enzymatic hydrolysis. The advantage of this effect could be in enzyme recycling, reduction of hydrolysis time or enzyme loading, leading to a lower enzyme cost of the lignocellulosic ethanol process, as has been suggested by other papers [50]. The enzyme adsorption and the effect of PEG were further investigated by various enzyme assays, which showed that PEG increased the concentration of various enzyme classes in the liquid fraction to a different extent. SDS-PAGE analysis of the hydrolysates confirmed the data achieved by the enzyme activity measurements of the individual components.

\section{Acknowledgements}

This work was financially supported by the Hungarian National Research Fund (OTKA-K 72710). The European Cooperation in the field of Scientific and Technical Research (COST Action FP0602, Biotechnology for Lignocellulose Biorefineries) and European Community Vocational Training Program (Leonardo da Vinci) are acknowledged for mobility support. Professor Guido Zacchi (Lund University, Department of Chemical Engineering) is gratefully acknowledged for the steam-pretreated spruce. Enzymes were kindly donated by Novozymes A/S (Bagsvaerd, Denmark).

\section{References}

[1] Sun Y, Cheng J. Hydrolysis of lignocellulosic materials for ethanol production: a review. Bioresour Technol 2002;83:1-11.

[2] Benkö Z, Siika-aho M, Viikari L, Réczey K. Evaluation of the role of xyloglucanase in the enzymatic hydrolysis of lignocellulosic substrates. Enzyme Microb Technol 2008;43:109-14.

[3] Berlin A, Gilkes N, Kilburn D, Bura R, Markov A, Skomarovsky A, et al. Evaluation of novel fungal cellulase preparations for ability to hydrolyze softwood substrates-evidence for the role of accessory enzymes. Enzyme Microb Technol 2005;37:175-84

[4] Yang B, Wyman CE. BSA treatment to enhance enzymatic hydrolysis of cellulose in lignin containing substrates. Biotechnol Bioeng 2006;94:611-7.

[5] Helle SS, Duff SJB, Cooper DG. Effect of surfactants on cellulose hydrolysis. Biotechnol Bioeng 1993;42:611-7. 
[6] Eriksson T, Börjesson J, Tjerneld F. Mechanism of surfactant effect in enzymatic hydrolysis of lignocellulose. Enzyme Microb Technol 2002;31:353-64.

[7] Mizutani C, Sethumadhavan K, Howley P, Bertoniere N. Effect of nonionic surfactant on Trichoderma cellulose treatments of regenerated cellulose and cotton yarns. Cellulose 2002;9:83-9.

[8] Kristensen JB, Börjesson J, Bruun MH, Tjerneld F, Jørgensen H. Use of surface active additives in enzymatic hydrolysis of wheat straw lignocellulose. Enzyme Microb Technol 2007;40:888-95.

[9] Börjesson J, Peterson R, Tjerneld F. Enhanced enzymatic conversion of softwood lignocellulose by poly(ethylene glycol) addition. Enzyme Microb Technol 2007;40:754-62.

[10] Börjesson J, Engqvist M, Sipos B, Tjerneld F. Effect of poly(ethylene glycol) on enzymatic hydrolysis and adsorption of cellulase enzymes to pretreated lignocellulose. Enzyme Microb Technol 2007;41:186-95.

[11] Castanon M, Wilke CR. Effects of the surfactant Tween 80 on enzymatic hydrolysis of newspaper. Biotechnol Bioeng 1981;23:1365-72.

[12] Park JW, Takahata Y, Kajiuchi T, Akehata T. Effects of nonionic surfactant on enzymatic hydrolysis of used newspaper. Biotechnol Bioeng 1992;39:11720.

[13] Ooshima H, Sakata M, Harano Y. Enhancement of enzymatic hydrolysis of cellulose by surfactant. Biotechnol Bioeng 1986;28:1727-34.

[14] Kaar WE, Holtzapple MT. Benefits from Tween during enzymatic hydrolysis of corn stover. Biotechnol Bioeng 1997;59:419-27.

[15] Alkasawari M, Eriksson T, Börjesson J, Wingren A, Galbe M, Tjerneld F, et al. The effect of Tween-20 on simultaneous saccharification and fermentation of softwood to ethanol. Enzyme Microb Technol 2006;33:71-8.

[16] Palonen H, Tjerneld F, Zacchi G, Tenkanen M. Adsorption of Trichoderma reesei CBH I and EG II and their catalytic domains on steam pretreated softwood and isolated lignin. J Biotechnol 2004;107:65-72.

[17] Karlsson J, Medve J, Tjerneld F. Hydrolysis of steam-pretreated lignocellulose-synergism and adsorption for cellobiohydrolase I and endoglucanase II of Trichoderma reesei. Appl Biochem Biotechnol 1999;82:24358.

[18] Mooney C, Mansfield S, Touhy M, Saddler J. The effect of the initial pore volume and lignin content on the enzymatic hydrolysis of softwoods. Bioresour Technol 1998;64:113-9.

[19] Donaldson LA, Wong KKY, Mackie KL. Ultrastructure of steam-exploded wood. Wood Sci Technol 1988;22:103-14.

[20] Lindström T, Glad-Nordmark G. Selective adsorption, flocculation, and fractionation of wood pulps with polyethyleneoxide. J Colloid Interface Sci 1983;94:404-11.

[21] Qing Q Yang B, Wyman CE. Impact of surfactants on pretreatment of corn stover. Bioresour Technol 2010, doi:10.1016/j.biortech.2010.03.003.

[22] Stenberg K, Tengborg C, Galbe M, Zacchi G. Optimisation of steam pretreatment of $\mathrm{SO}_{2}$-impregnated mixed softwoods for ethanol production. J Chem Technol Biotechnol 1998;71:299-308.

[23] Kovács K, Szakacs G, Zacchi G. Comparative enzymatic hydrolysis of pretreated spruce by supernatants, whole fermentation broths and washed mycelia of Trichoderma reesei and Trichoderma atroviride. Bioresour Technol 2009;100:1350-7.

[24] Suurnäkki A, Tenkanen M, Siika-aho M, Niku-Paavola M-L, Viikari L, Buchert J. Trichoderma reesei cellulases and their core domains in the hydrolysis and modification of chemical pulp. Cellulose 2000;7:189-209.

[25] Tengborg C, Galbe M, Zacchi G. Influence of enzyme loading and physical parameters on the enzymatic hydrolysis of steam-pretreated softwood. Biotechnol Progr 2001; 17:110-7.

[26] Mandels M, Andreotti R, Roche C. Measurement of saccharifying cellulase. Biotechnol Bioeng Symp 1976;6:21-33.

[27] Berghem LER, Pettersson G. The mechanism of enzymatic cellulose degradation. Eur J Biochem 1974;46:295-305.

[28] van Tilbeurgh H, Clayssens M, Bruyne CK. The use of 4-methylumbelliferyl and other chromophoric glycosides in the study of cellullytic enzymes. FEBS Lett 1982;149:152-6.
[29] van Tilbeurgh H, Loontiens FG, de Bruyne CK, Clayssens M. Fluorogenic and chromogenic glycosides as substrates and ligands of carbohydrates. Method Enzymol 1988;160:45-59.

[30] Miller GL. Use of dinitrosalicylic acid reagent for determination of reducing sugar. Anal Chem 1959;31:426-8.

[31] Bradford MM. A rapid and sensitive method for the quantitation of microgram quantities of protein utilizing the principle of protein-dye binding. Anal Biochem 1976;72:248-54.

[32] Sluiter A, Hames B, Ruiz R, Scarlata C, Sluiter J, Templeton D, et al. (2008). Determination of Structural Carbohydrates and Lignin in Biomass, Laboratory Analytical Procedure, NREL Report No. TP-510-42618.

[33] Neuhoff V, Arold N, Taube D, Ehrhardt W. Improved staining of proteins in polyacrylamide gels including isoelectric focusing gels with clear background at nanogram sensitivity using Coomassie Brilliant Blue G-250 and R-250. Electrophoresis 1988;9:255-62.

[34] Argyropoulos DS. Quantitative phosphorus-31 NMR analysis of lignins, a new tool for the lignin chemist. J Wood Chem Technol 1994;14:45-63.

[35] Archipov Y, Argyropoulos DS, Bolker HI, Heitner C. ${ }^{31} \mathrm{P}$ NMR spectroscopy in wood chemistry. I. Model compounds. J Wood Chem Technol 1991;11:137-57.

[36] Crestini C, Argyropoulos DS. Structural analysis of wheat straw lignin by quantitaitve ${ }^{31} \mathrm{P}$ and 2D NMR spectroscopy. The occurrence of ester bonds and $\alpha-\mathrm{O}-4$ substructures. Agric Food Chem 1997;45:1212-9.

[37] Granata A, Argyropoulos DS. 2-Chloro-4,4,5,5-tetramethyl-1,3,2dioxaphospholane, a reagent for the accurate determination of the uncondensed and condensed phenolic moieties in lignins. J Agric Food Chem 1995;43:1538-44.

[38] Jiang ZH, Argyropoulos DS, Granata A. Correlation analysis of ${ }^{31} \mathrm{P}$ NMR chemical shifts with substituent effects of phenols. Magn Reson Chem 1995;33:375-82.

[39] Sutcliffe R, Saddler JN. The role of lignin in the adsorption of cellulases during enzymatic treatment of lignocellulosic material. Biotechnol Bioeng Symp 1986;17:749-62.

[40] Lu Y, Yang B, Gregg D, Saddler JN, Mansfield S. Cellulase adsorption and an evaluation of enzyme recycle during hydrolysis of steam-exploded softwood residues. Appl Biochem Biotechnol 2002;98-100:641-54.

[41] Puls J, Poutanen K, Kürner H-U, Viikari L. Biotechnical utilization of wood carbohydrates after steaming pretreatment. Appl Microbiol Biotechnol 1985;22:416-23.

[42] Macarron R, Acebal C, Castillon MP, Dominguez JM, de la Mata I, Pettersson G, et al. Mode of action of endoglucanase III from Trichoderma reesei. Biochem J 1993;289:867-73.

[43] Eriksson T, Karlsson J, Tjerneld F. A model explaining declining rate in hydrolysis of lignocellulose substrates with cellobiohydrolase I(Cel7A) and endoglucanase I (Cel7B) of Trichoderma reesei. Appl Biochem Biotechnol 2002;101:41-60.

[44] Karlsson J, Siika-aho M, Tenkanen M, Tjerneld F. Enzymatic properties of the low molecular mass endoglucanases Cel12A (EG III) and Cel45A (EG V) of Trichoderma reesei. J Biotechnol 2002;99:63-78.

[45] Lynd LR, Weimer PJ, van Zyl WH, Pretorius IS. Microbial cellulose utilization: fundamentals and biotechnology. Microbiol Mol Biol R 2002;66:506-77.

[46] Nidetzky B, Clayessens M. Specific quantification of Trichoderma reesei cellulases in reconstituted mixtures and its application to cellulase cellulose binding studies. Biotechnol Bioeng 1994;44:961-6.

[47] Saloheimo M, Lehtovaara P, Penttilä M, Teeri TT, Stihlberg J, Johansson G, et al. EGIII, a new eudoglucanase from Trichoderma reesei: the characterization of both gene and enzyme. Gene 1988;63:11-21.

[48] Jääskeläinen AS, Sun Y, Argyropoulos DS, Tamminen T, Hortling B. The effect of isolation method on the chemical structure of residual lignin. Wood Sci Technol 2003;37:91-102.

[49] Li J, Gellerstedt G, Toven K. Steam explosion lignins; their extraction, structure and potential as feedstock for biodiesel and chemicals. Bioresour Technol 2009;100:2556-61.

[50] Tu M, Saddler JN. Potential enzyme cost reduction with the addition of surfactant during the hydrolysis of pretreated softwood. Appl Biochem Biotechnol 2010;161:274-87. 